\title{
Combustion, Performance and Emission Characteristics of Diesel Engine with Neem Oil Methyl Ester and its Diesel Blends
}

\author{
${ }^{1}$ L. Prabhu, ${ }^{2}$ S. Sathish Kumar, ${ }^{3}$ M. Prabhahar and ${ }^{4}$ K. Rajan \\ ${ }^{1}$ Sathyabama University, Chennai, India \\ ${ }^{2}$ St.Joseph's College of Engineering, Chennai, India \\ ${ }^{3}$ Aarupadai Veedu Institute of Technology, Chennai, India \\ ${ }^{4}$ Dr.MGR Educational Research Institute University, Chennai, India
}

Received 2013-03-25, Revised 2013-07-02; Accepted 2013-07-09

\begin{abstract}
Biodiesel, an alternative fuel is derived from the fats of animals and plants. As energy demands increase and fossil fuels are limited, research is directed towards alternative renewable fuels. The main advantages of using this alternative fuel are its renewability, biodegradability and better quality of exhaust gases. It is technically competitive and environmentally friendly alternative to conventional petro-diesel fuel for use in Compression Ignition (CI) engines. The use of biodiesel reduces the dependence on imported fossil fuels which continue to decrease in availability and affordability. An experimental investigation has been carried out to evaluate the combustion, performance and emission characteristics of a diesel engine with the effect of using neem oil methyl ester and its diesel blends at different loads. The results showed that maximum cylinder pressure and maximum rate of heat release increased with the increase in bio diesel blends. The carbon monoxide (CO) and smoke emissions were found significantly lower when operating on biodieseldiesel blends, but Nitrogen Oxide (NOx) emissions are found to be higher at full load.
\end{abstract}

Keywords: Compression Ignition, Diesel Blends, Diesel Engine, Rubber Seed Oil

\section{INTRODUCTION}

Vegetable oil is one of the alternatives which can be used as fuel for automotive engines either in the form of straight vegetable oil or in the form of methyl ester. The energy needs of the world are increasing rapidly. The decrease in fossil fuels, emission pollution caused by them and increasing fuel prices make biomass energy sources more attractive. The increase in energy demand and decrease in oil reserves have been focused on biofuels. Biodiesel is a fuel that is manufactured from vegetable oils with the help of catalysts and may be directly used in diesel vehicles with little or no modification. The biodiesel is reported to be sulfur-free, nontoxic, biodegradable oxygenated and renewable and the characteristics of biodiesel are very close to diesel fuel (Gerhard, 1983; Murayama, 1984) and some are better than diesel such as higher cetane number, no aromatics, almost no sulfur and more than $10 \%$ oxygen by weight, which reduce the emission of carbon monoxide, unburned hydrocarbon and volatile organic compounds (Agarwal, 2007; Kegl, 2008). An experimental study is carried out to evaluate and compare the use of cottonseed oil, soybean oil, sunflower oil and their corresponding methyl esters. It shows that all tested biodiesel or vegetable oil blends, can be used safely (Altın et al., 2001; Rakopoulos et al., 2006). Gattamaneni et al. (2008) have investigated the performance of diesel engine with rice bran oil methyl ester and its diesel blends. They have reported that the $\mathrm{CO}, \mathrm{HC}$ and soot emissions were increased and the NOx emissions were slightly increased with increase in blends compared to diesel fuel operation. Also the ignition delay and the peak heat release rate for RBME were

Corresponding Author: L. Prabhu, Sathyabama University, Chennai, India 
lower for biodiesel and it was increased with increase in RBME blends. Pramanik (2003) reported that up to $50 \%$ Neem oil could be substituted for diesel for use in a diesel engine without any major operational difficulties. Agarwal (1998) have studied the combustion characteristics of a DI diesel engine with rice bran oil methyl ester and its blends. He reported that the combustion duration and ignition delay increased with vegetable oil compared to diesel. The $\mathrm{CO}$ and smoke emissions were decreased while the NOx emissions were increased with increase in blends. Kumar et al. (2003) have studied on a direct injection diesel engine with $30 \%$ methanol as duel fuel with Jatropha oil and neat Jatropha methyl esters. Their results showed that the thermal efficiency is improved and smoke emissions and nitric oxides emissions were decreased with duel fuel with $30 \%$ methanol and JME blends. The ignition delay was higher for Jatropha oil and it is reduced for Jatropha oil methyl ester.

Geo et al. (2008) have studied the combustion process of Rubber Seed Oil (RSO) and its methyl ester (RSOME) and also reported higher emissions of $\mathrm{CO}, \mathrm{HC}$ and smoke and lower NOx as compared to that of diesel. Balusamy and Marappan (2008) have experimented with Methyl Ester of Thevetia Peruviana Seed Oil (METPSO) and reported a lower emission of $\mathrm{CO}, \mathrm{HC}$ and a higher NOx as compared to that of diesel. Banapurmath et al. (2008) have conducted test with Jatropha, Karanja and Polanga methyl ester in a Diesel engine. They reported that higher peak cylinder pressure and shorter ignition delay for all biodiesels when compared with diesel. Sahoo and Das (2009) have conducted the experiment with methyl esters of Honge (HOME), Jatropha (JOME) and Sesame (SOME) in a single cylinder, four stroke, direct injection Compression Ignition (CI) engine and reported that the higher emission of $\mathrm{CO}, \mathrm{HC}$ and smoke and lower $\mathrm{NO}$ as compared to that of diesel. In this experimental study, the biodiesel from different non-edible oils was produced by a method of alkaline-catalyzed transesterification. Rajan and Kumar (2010) have studied the performance of a diesel engine with internal jet piston using biodiesel. They reported that the brake thermal efficiency is increased; the $\mathrm{CO}$ and Smoke emissions are decreased at full load. The NO emission is increased at full load compared to diesel fuel with the base diesel engine. The objectives of this experimental study are to assess the performance, combustion and emission characteristics of a diesel engine with Neem oil methyl ester diesel blends and compared with diesel fuel.

\section{MATERIALS AND METHODS}

\subsection{Biodiesel Preparation}

Neem oil was converted into its methyl ester by the transesterification process. This involves making the triglycerides of Jatropha oil to react with methyl alcohol in the presence of catalyst $(\mathrm{NaOH} / \mathrm{KOH})$ to produce glycerol and fatty acid ester. Specified amount (1000 $\mathrm{mL})$ of Jatropha oil $(450 \mathrm{~mL})$ of methyl alcohol and $(10 \mathrm{~g})$ of sodium hydroxide were taken in a round bottom flask. The contents were stirred till ester formation began. The mixture was heated to $70^{\circ} \mathrm{C}$ and held at that temperature with constant speed stirring for $1 \mathrm{hr}$ and then it was allowed to cool overnight without stirring. Two layers were formed. The bottom layer consisted of glycerol and top layer was the ester. The properties of diesel, Neem oil and methyl ester of Neem oil are given in Table 1.

\subsection{Test Engine and Experimental Procedure}

Experiments have been conducted in a singlecylinder, four-stroke, naturally aspirated, direct injection Diesel engine (Fig. 1). The specification of the engine is given in Table 1. Two separate fuel tanks were used for the diesel fuel and neem oil methyl ester. The volumetric fuel flow rate and the volumetric air flow rate were measured using a $50 \mathrm{~cm}^{3}$ burette/stop watch and a Utube fuel to flow into the engine. The engine is coupled with an eddy current dynamometer which is used to control the engine torque. Engine speed and load are controlled by varying excitation current to the eddy current dynamometer using dynamometer controller.

A kistler piezoelectric transducer (water cooled type) is installed in the cylinder head in order to measure the combustion pressure. Signals from pressure transducer are fed to charge amplifier. A high precision crank angle encoder is used for delivering signals for Top Dead Center (TDC) and crank angle. The signals from charge amplifier and crank angle encoder are acquired using data acquisition system (12 bit). Incylinder pressure and TDC signal are acquired and stored on a high speed computer based digital data acquisition system. The data from 50 consecutive cycles are recorded. These are processed with specially developed Lab view software to obtain the pressure crank angle data. A program has been developed to obtain the average pressure crank angle data of 50 cycles. An AVL exhaust-gas analyzer (Model: DiGas 444) and Bosch Smoke meter are used to measure emission parameters $\mathrm{CO}, \mathrm{HC}, \mathrm{NO}$ and smoke intensity, respectively. 
Table 1. Properties of diesel, Neem oil and its methyl ester

\begin{tabular}{lrrr}
\hline Properties & Diesel & Neem oil & NOME \\
\hline Specific gravity & 0.83 & 0.92 & 0.86 \\
Kinematic Viscosity at $40^{\circ} \mathrm{C}(\mathrm{cSt})$ & 3.72 & 38.00 & 4.50 \\
Flash point $\left({ }^{\circ} \mathrm{C}\right)$ & 62.00 & 350.00 & 152.00 \\
Fire point $\left({ }^{\circ} \mathrm{C}\right)$ & 64.00 & 365.00 & 180.00 \\
Calorific value $(\mathrm{kJ} / \mathrm{kg})$ & 42500.00 & 39500.00 & 38500.00 \\
Cetane No & 48.00 & 38.00 & 51.00 \\
Oxygen Content & - & $12.00 \%$ & $12.00 \%$ \\
\hline
\end{tabular}

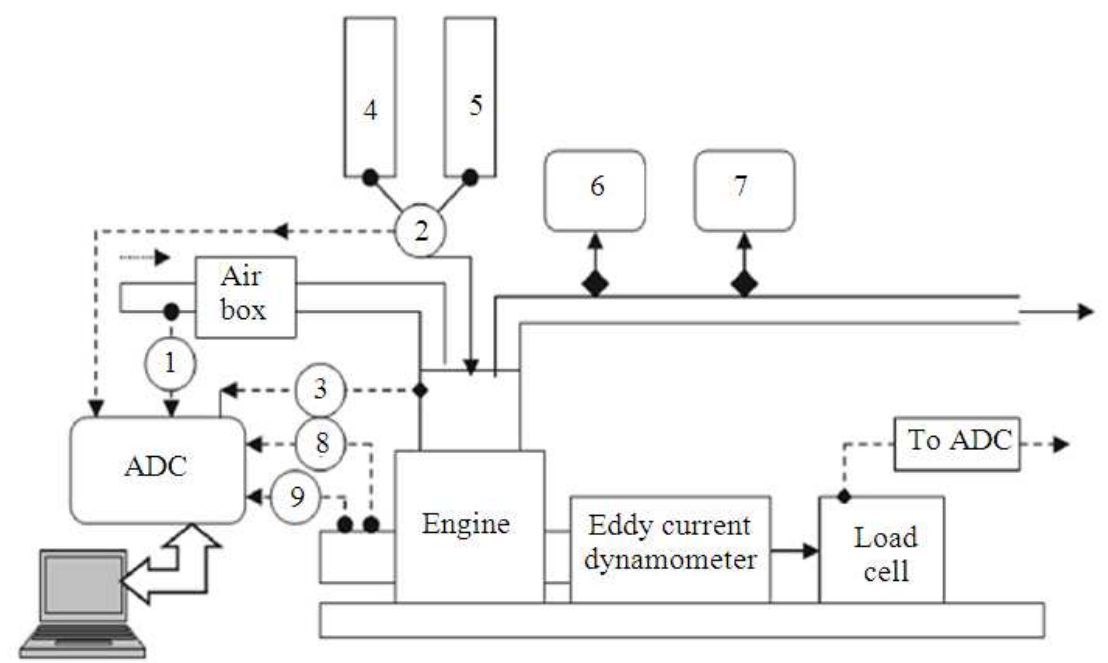

1-Air flow sensor, 2-Fuel flow sensor, 3-Pressure sensor, 4-Diesel tank, 5-Biodiesel tank, 6-Five gas analyzer, 7-Smoke meter, 8-Speed sensor, 9-Crank angle encoder

Fig. 1. Schematic of the experimental setup

The engine is operated at the rated speed of 1500 rpm for all the tests. For all the tests, the engine is started with diesel fuel and allowed to stabilize for $30 \mathrm{~min}$. After the engine is warmed up, it is then switched to NOME diesel blends. For each experiment, three measurements are taken to average the data so as to determine the repeatability of the measured data and have an estimate of measured accuracy. At the end of test, the fuel is switched back to diesel and the engine is kept running for a while before shutdown to flush out the NOME diesel blends from the fuel lines and injection system. The performance parameter such as Brake Thermal Efficiency (BTE) and brake Specific Energy Consumption (BSFC), combustion parameters such as cylinder pressure, rate of heat release and emission parameters such as like smoke intensity, $\mathrm{HC}, \mathrm{CO}$ and NO emissions are measured for diesel fuel and NOME diesel blends. Finally, the test results are analyzed and compared with the diesel fuel.

\section{RESULTS AND DISCUSSION}

\subsection{Combustion Analysis}

The variation of cylinder pressure with crank angle at full load is shown in Fig. 2. In a CI engine, the cylinder pressure characterizes the ability of fuel to mix well with air and burn. It is clear that the combustion starts earlier for NOME and 20\% NOME due to shorter ignition delay. It is observed that $20 \%$ NOME has a higher peak pressure than $100 \%$ NOME and diesel. It may be due to more fuel is accumulated in the combustion chamber which leads to higher peak pressure at the time of premixed combustion stage. The higher peak pressure for $20 \%$ NOME as compared to diesel may also be due to dynamic injection advance, which results in initiation of combustion before TDC and the pressure rises quickly. The peak pressure for 20\% NOME and $100 \%$ 
NOME is 68.6 bar and 64.5 bar respectively, while in the case of diesel, it is 67 bar at full load.

The variation of heat release rate with crank angle at full load is shown in Fig. 3. It is observed that the heat release rate is higher for diesel than 20\% NOME and $100 \%$ NOME at full load. This may be due to higher volatility and better mixing of diesel with air. Another reason may be, as a consequence of the longer ignition delay, the intensity of premixed combustion phase for diesel is more. On the other hand, the peak heat release rate is lower for $100 \%$ NOME compared to $20 \% \mathrm{NOME}$ and diesel. This may be due to the lower volatility and higher viscosity of NOME, it leads to a reduction in air entrainment and fuel-air mixing rates, resulting in lesser amount of fuel being prepared for premixed combustion stage during ignition delay. It can also be observed the diffusion burning indicated by the area under second peak is dominant for $100 \%$ NOME.

\subsection{Performance Analysis}

The variation of brake thermal efficiency with brake power for diesel and neem biodiesel is shown in Fig. 4. The thermal efficiency is lower for B100 that of B20 and diesel. It may be due to larger differences in viscosity, specific gravity and volatility between diesel and B20. Poor spray formation and reduced spray angle causes reduction in air entrainment and fuel-air mixing rates (Murayama, 1984). The B20 NOME has a lower viscosity, which results in better atomization that leads to complete combustion of the fuel as compared to $100 \%$ Neem methyl ester.

Figure 5 shows the variation in brake fuel consumption for diesel and neem biodiesel. The BSFC is an important parameter to evaluate engines performance and determine the fuel efficiency of an engine. The BSFC of diesel engine decreases as the engine brake loads are increased. The brake specific fuel consumption of Neem biodiesel is increased for B20, B100 than that of diesel at full load. It is observed that the BSFC of $\mathrm{B} 20$ blends is lower in comparison to neat neem biodiesel. It is observed that the BSFC of B100 is higher than that of diesel fuel when the blends are B20 and $\mathrm{B} 100$ are used in diesel engine.

Figure 6 shows the variation of the exhaust gas temperature with brake power for diesel and its biodiesel blends. It can be noticed that the exhaust gas temperature increases with an increase in the load for all the fuels. The exhaust gas temperature for B20, B40 and B100 are 320,332 and $341^{\circ} \mathrm{C}$ respectively, whereas for diesel, $302^{\circ} \mathrm{C}$ at full load. The higher values of the exhaust gas temperature can be attributed to the slow combustion of neem biodiesel compared to diesel fuel. It can also be observed that the ignition delay is longer for raw Jatropha oil, resulting in slow combustion, which reflects in higher exhaust gas temperatures.

\subsection{Emission Analysis}

The variation of carbon monoxide $(\mathrm{CO})$ with brake power for diesel and biodiesel blends is presented in Fig. 7. The fuels are producing higher amount of carbon monoxide emission at low power outputs and giving lower values at higher power conditions. Carbon monoxide emission increases at full load for all the fuels. With increasing biodiesel percentage, $\mathrm{CO}$ emission level decreases. It can be observed that the $\mathrm{CO}$ emissions are lower for $\mathrm{B} 100 \%$ as compared to diesel and B20 and $\mathrm{B} 40$ and $\mathrm{B} 100$ are $0.5 \% \mathrm{Vol}, 0.55 \% \mathrm{Vol}$ and $0.04 \% \mathrm{Vol}$, whereas for diesel, it is $0.55 \% \mathrm{Vol}$ at full load. This may be due to relatively poor atomization and lower volatility of NOME blends as compared to diesel. The another reason may also that the biodiesel itself has about $11 \%$ oxygen content in it and it may helps for the complete combustion at full load. Hence, CO emission level decreases with increasing biodiesel percentage in the fuel as compared with the diesel fuel.

The variation of Hydrocarbon (HC) with respect to brake power for diesel and biodiesel blends is presented in Fig. 8. It can be observed that the $\mathrm{HC}$ emissions are higher with $\mathrm{B} 100 \%$ as compared to diesel and B20 and $\mathrm{B} 40$ and $\mathrm{B} 100$ are $36 \mathrm{ppm}, 41 \mathrm{ppm}$ and $48 \mathrm{ppm}$ at full load, whereas for diesel it is $32 \mathrm{ppm}$ at full load. This increase in $\mathrm{HC}$ emission for biodeisel blends may be due to relatively poor atomization and lower volatility of NOME blends as compared to diesel.

The variation of $\mathrm{NO}_{\mathrm{x}}$ emission with respect to brake power for diesel and biodiesel blends is presented in Fig. 9. The result shows that the diesel fuel is having lower $\mathrm{NO}$ emission and blends of Neem oil are having higher NO emission. Compared to conventional fuel the NO emission is increased by $5 \%$ with the blend of Neem oil. The presence of oxygen in NOME helps to produce more amount of NO. The impact of fuel injection also plays a role in the higher NO emissions in the NOME.

Figure 10 represents smoke emission with respect to brake power for diesel and biodiesel blends. The smoke emission with respect to different loads was analyzed for various blends of fuel. The results confirm that smoke emission for biodiesel blend to be lower for NOME than that of the diesel fuel. $20 \%$ blend show low smoke number contributing to the factor that lesser amount of unburnt hydrocarbons is present in the engine exhaust emission. This may be due to the presence of oxygen molecule present in the neem oil methyl ester helps for complete combustion. 
L. Prabhu et al. / American Journal of Applied Sciences 10 (8): 810-818, 2013

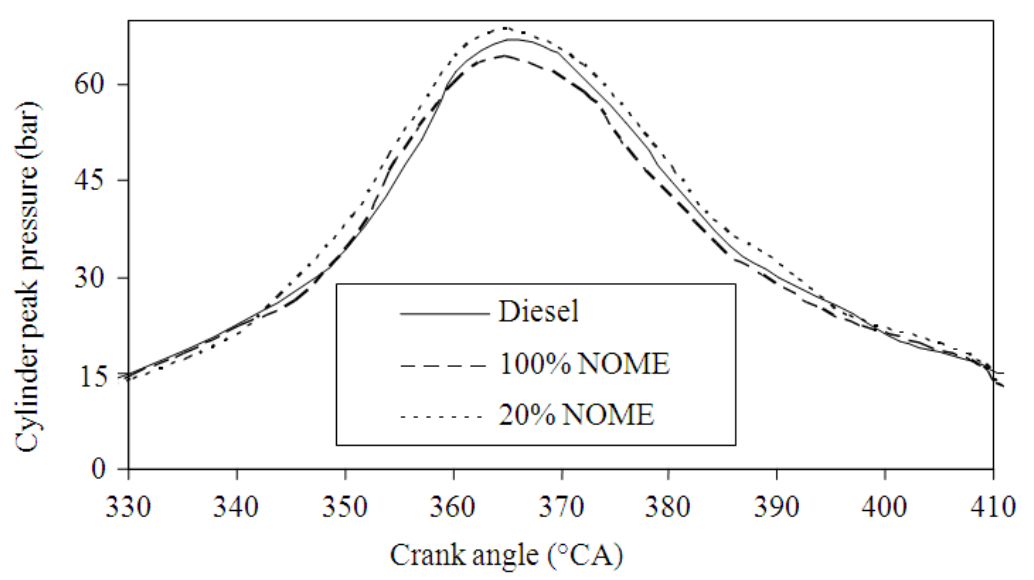

Fig. 2. Variation of cylinder pressure with crank angle

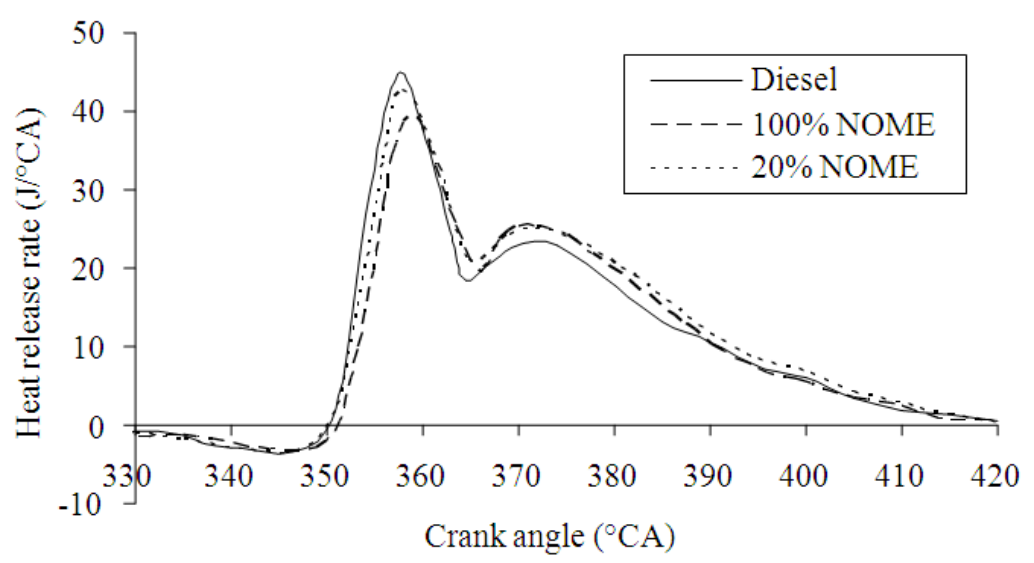

Fig. 3. Variation of Heat release rate with crank angle

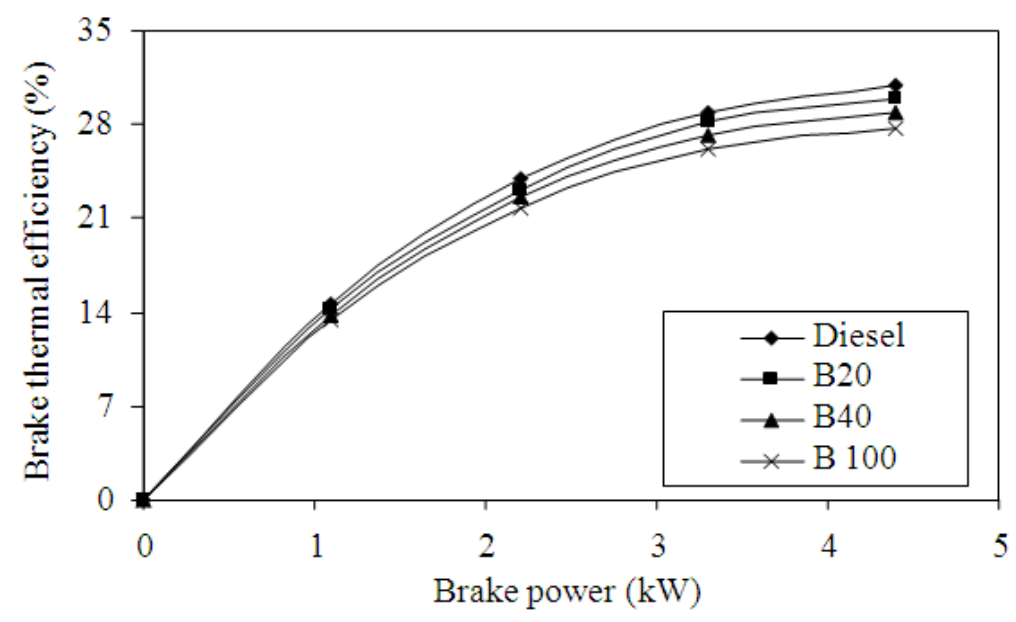

Fig. 4. Variation of brake thermal efficiency with BP 
L. Prabhu et al. / American Journal of Applied Sciences 10 (8): 810-818, 2013

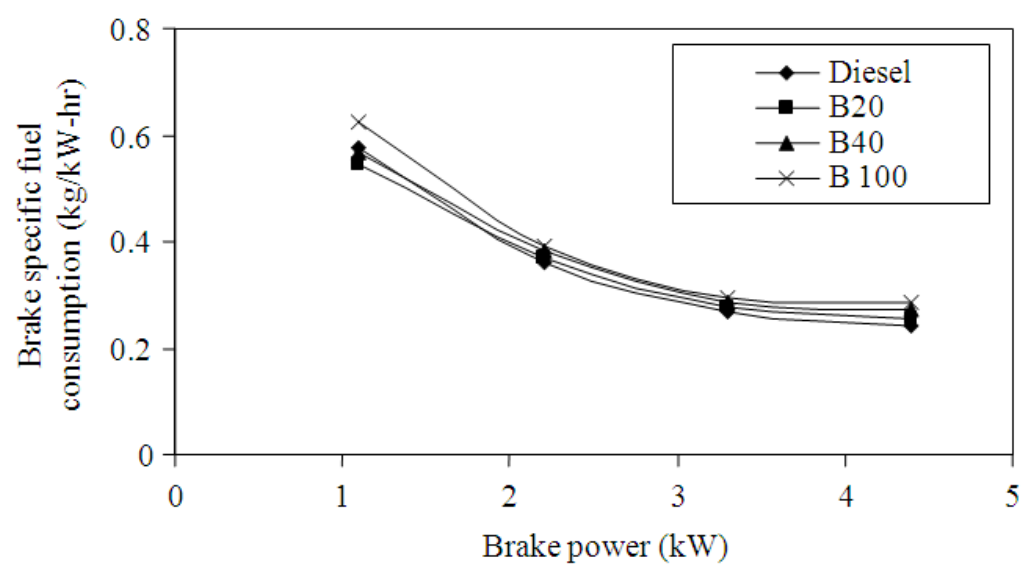

Fig. 5. Variation of specific fuel consumption with BP

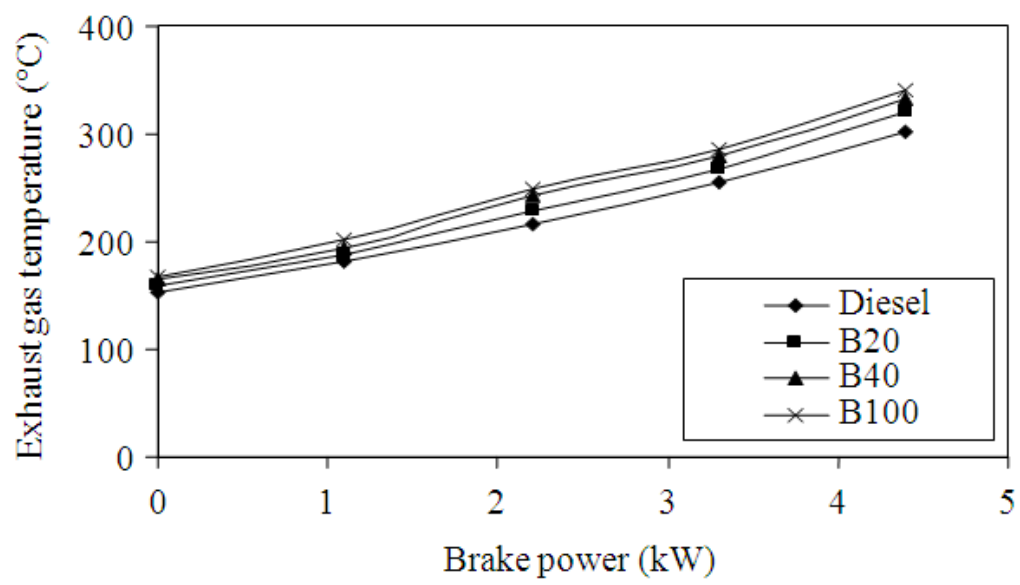

Fig. 6. Variation of exhaust gas temperature with brake power

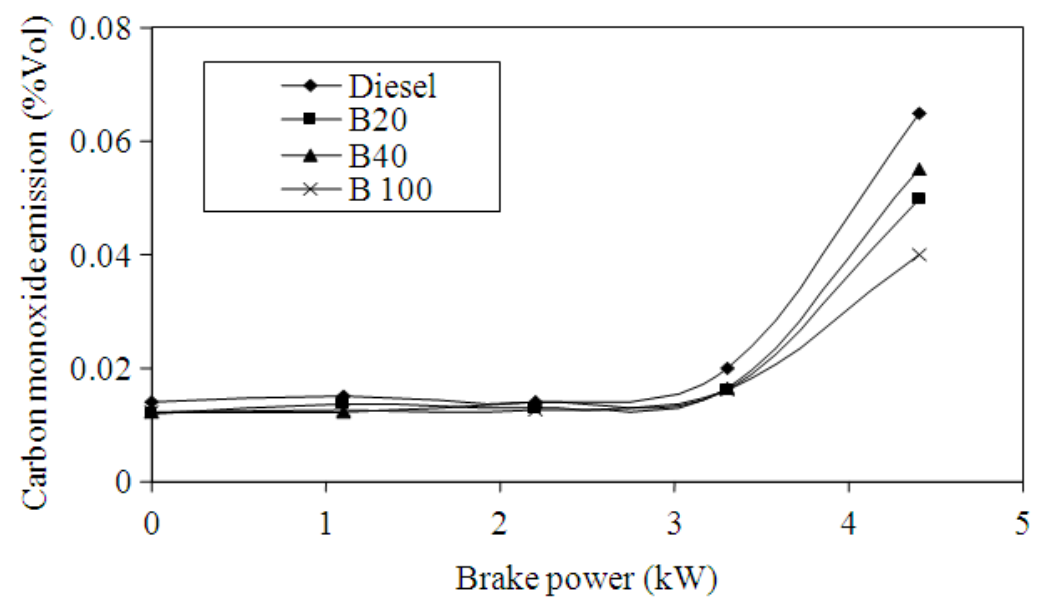

Fig. 7. Variation of carbon monoxide with brake power 
L. Prabhu et al. / American Journal of Applied Sciences 10 (8): 810-818, 2013

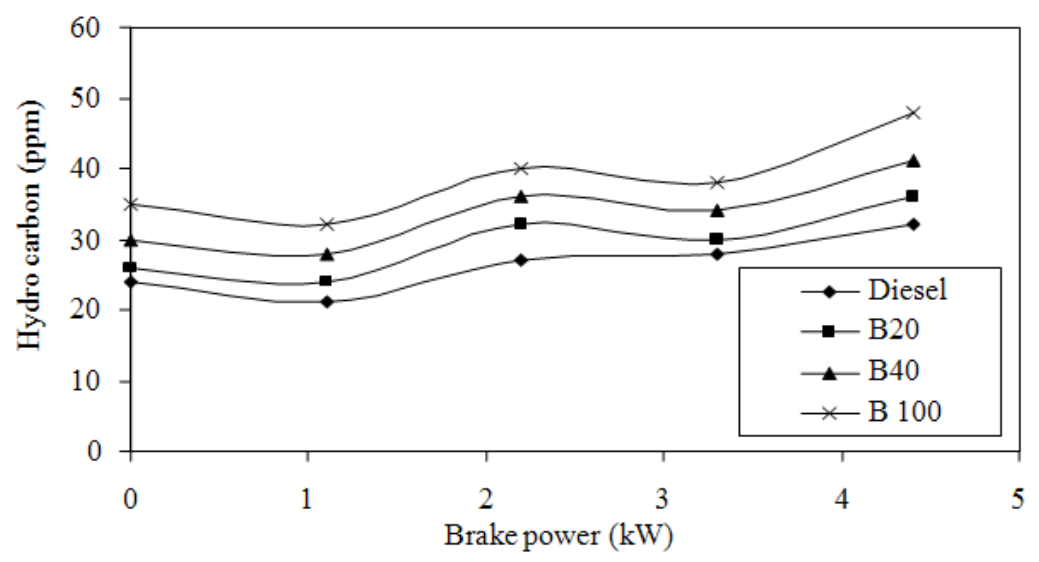

Fig. 8. Variation of hydro carbon with brake power

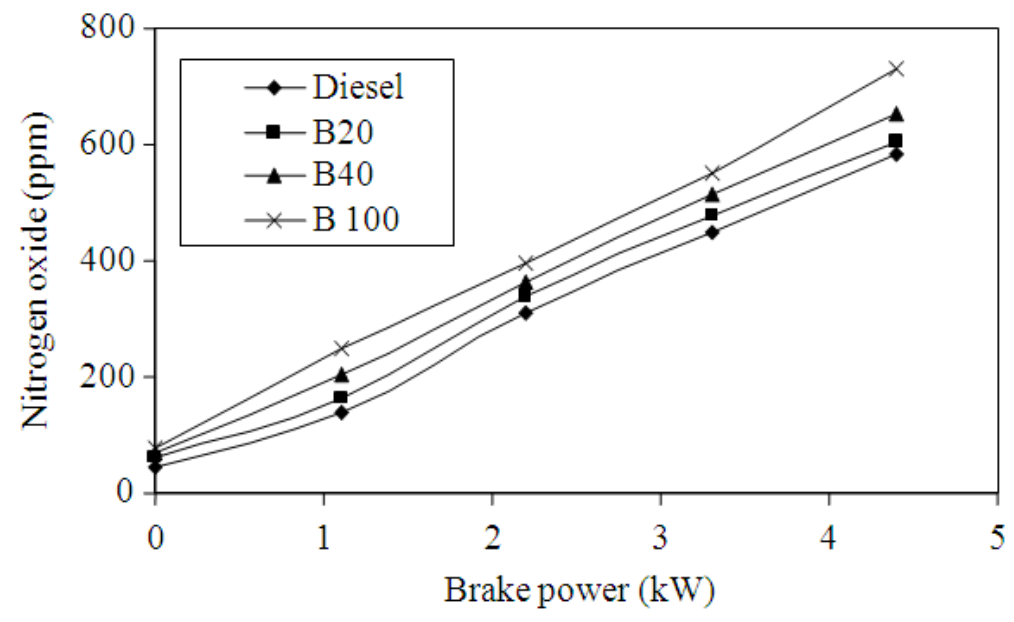

Fig. 9. Variation of nitrogen oxide with brake power

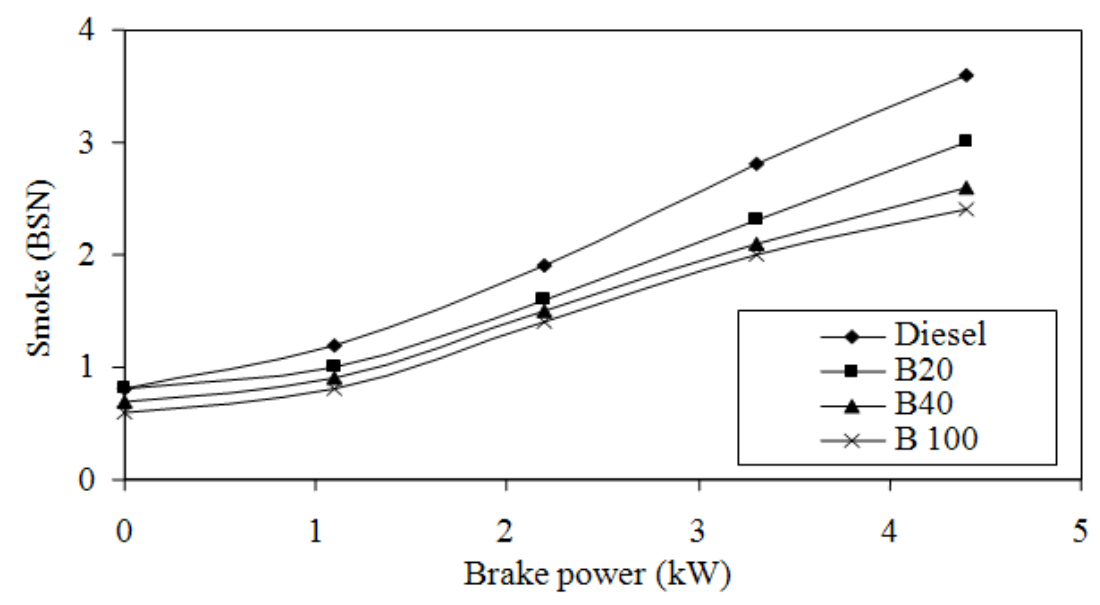

Fig. 10. Variation of smoke with brake power 
Table 2. Test engine specifications

\begin{tabular}{ll}
\hline Make & Kirloskar, single cylinder \\
\hline Engine & Four stroke, diesel engine \\
Type & Vertical, water cooled engine \\
Bore Diameter & $87.5 \mathrm{~mm}$ \\
Stroke Length & $110 \mathrm{~mm}$ \\
Brake Power & $4.44 \mathrm{~kW}$ \\
Compression Ratio & $17.5: 1$ \\
Speed & $1500 \mathrm{rpm}$ \\
Fuel injection & $23^{\circ}$ before TDC \\
\hline
\end{tabular}

\section{CONCLUSION}

A single cylinder diesel engine is operated successfully on diesel and NOME diesel blends. The following conclusions are drawn based on the experimental results:

- $\quad$ The BTE and BSFC for 20,40 and 100\% NOME are lower than that of diesel fuel at full load

- From the emission analysis it is observed that there is a 10,15 and $20 \%$ increase in NO emission for 20 , 40 and $100 \%$ NOME at full load as compared to diesel fuel

- The CO emissions are lowered by 23,30 and $40 \%$ for 20, 40 and 100\% NOME at full load as compared to diesel fuel

- The HC emissions from 20, 40 and 100\% NOME blends are increased as compared to that of diesel

- The smoke emissions from 20, 40 and 100\% NOME blends decreased by 25 and $33 \%$ for at full load

- The peak cylinder pressure for 20\% NOME is closer to diesel fuel and it is slightly higher than $100 \%$ NOME at full load. The rate of heat release rate during the premixed combustion phase and it is lower for $20 \%$ NOME and $100 \%$ NOME as compared to diesel

- On the whole, it can be concluded that the performance, combustion and emission characteristics of $20 \%$ NOME blend are better compared to $100 \%$ NOME. Hence, biodiesel from Neem oil is quite suitable as an alternative to diesel fuel

\section{REFERENCES}

Agarwal, A.K., 1998. Vegetable oils versus diesel fuel: Development and use of bio-diesel in a compression ignition engine. TERI Inform. Digest Energy, 8: 191-203.
Agarwal, A.K., 2007. Biofuels (alcohols and biodiesel) applications as fuels for internal combustion engines. Prog. Energy Combust. Sci., 33: 233-271. DOI: $10.1016 /$ j.pecs.2006.08.003

Altın, R., C. Selim and H.S. Yucesu, 2001. The potential of using vegetable oil fuels as fuel for diesel engines. Energy Conversion Manage., 42: 529-538. DOI: 10.1016/S0196-8904(00)00080-7

Balusamy, T. and R. Marappan, 2008. Comparative study of thevetia peruviana seed oil with other biofuels and diesel as fuel for CI engine. Int. J. Applied Eng. Res.

Banapurmath, N.R., P.G. Tewaria and R.S. Hosmath, 2008. Performance and emission characteristics of a DI compression ignition engine operated on Honge, Jatropha and sesame oil methyl esters. Renew. Energy, 33: 1982-1988. DOI: 10.1016/j.renene.2007.11.012

Gattamaneni, L.N.R., S. Saravanan, S. Sampath and K. Rajagopal, 2008. Combustion and emission characteristics of diesel engine fuelled with rice bran oil methyl ester and its diesel blends. Thermal sci., 12: 139-150.

Geo, V.E., G. Nagarajan and B. Nagalingam, 2008. A Comparative combustion analysis of rubber seed oil and its methyl ester in a D.I. diesel engine. SAE Technical Paper. DOI: 10.4271/2008-01-1386

Gerhard, V., 1983. Performance of Vegetable Oils and their Monoesters as Fuels for Diesel Engines. 1st Edn., Society of Automotive Engineers, Warrendale, pp: 10 .

Kegl, B., 2008. Effects of biodiesel on emissions of a bus diesel engine. Bioresour. Technol., 99: 863-873. DOI: 10.1016/j.biortech.2007.01.021

Kumar, M.S., A. Ramesh and B. Nagalingam, 2003. An experimental comparison of methods to use methanol and Jatropha oil in a compression ignition engine. Biomass Bioenergy, 25: 309-318. DOI: 10.1016/S0961-9534(03)00018-7

Murayama, T., 1984. Low Carbon Flower Buildup, Low Smoke and Efficient Diesel Operation with Vegetable Oils by Conversion to Mono-Esters and Blending with Diesel Oil or Alcohols. 1st Edn., Society of Automotive Engineers, Warrendale, pp: 11 .

Pramanik, K., 2003. Properties and use of jatropha curcas oil and diesel fuel blends in compression ignition engine. Renew. Energy, 28: 239-248. DOI: 10.1016/S0960-1481(02)00027-7 
Rajan, K. and K.R.S. Kumar, 2010. Performance and emission characteristics of DI diesel ignition engine with biodiesel using internal jet piston. Environ. Stud., 64: 1982-1988.

Rakopoulos, C.D, K.A. Antonopoulos and D.C. Rakopoulos, 2006. Multi-zone modeling of diesel engine fuel spray development with vegetable oil, bio-diesel or diesel fuels. Energy Conversion Manage., $\quad 47$ : 1550-1573. DOI: 10.1016/j.enconman.2005.08.005
Sahoo, P.K. and L.M. Das, 2009. Combustion analysis of Jatropha, Karanja and Polanga based biodiesel as fuel in a diesel engine. Fuel, 88: 994-999. DOI: 10.1016/j.fuel.2008.11.012 